\title{
Subsidence rate of Ljubljansko barje in Holocene
}

\section{Hitrost posedanja Ljubljanskega barja v holocenu}

\author{
Mihael BRENČIČ \\ Geološki zavod Slovenije, Dimičeva ul. 14, Ljubljana \\ Oddelek za geologijo, NTF, Univerza v Ljubljani, Aškerčeva 12, Ljubljana \\ e-mail: mbrencic@geo-zs.si
}

Key words: subsidence, consolidation, sedimentation, neotectonic, pollen diagrams, sediment age, Holocene, Ljubljansko barje

Ključne besede: posedanje, konsolidacija, sedimentacija, neotektonika, pelodni diagrami, starost sedimenta, holocen, Ljubljansko barje

\begin{abstract}
The article analyses the rate of subsidence of Ljubljansko barje (the Ljubljana marshland) during Holocene. The analysis is based on the reinterpretation of data from pollen diagrams taken in the BV-1 borehole north of Podpeč and in the borehole BV-2 south of Crna vas. The reinterpretation was carried out on the basis of comparison with absolutely dated pollen diagrams in the sediment of Podpeško jezero and diagrams at other locations in Slovenia. The main markers, which the reinterpretation is based on, are the Pinus, the concentration of which starts decreasing at $11.2 \mathrm{ka}$, and the occurrence of Fagus and Abies. The concentration of Fagus starts rising at $8.7 \mathrm{ka}$, and Abies reaches its peak at $6.4 / 6.9 \mathrm{ka}$ and at $3.0 \mathrm{ka}$. On the basis of relation between age and depth at which the sediment occurs a simple sedimentation-consolidation model was constructed, showing that the neotectonic subsidence of the Ljubljana Moore in Holocene was uniform. The subsidence in the area of borehole BV-1 was $1.24 \mathrm{~m} / \mathrm{ka}$ and the subsidence in the area of borehole BV-2 $1.36 \mathrm{~m} / \mathrm{ka}$. The article also poses the hypothesis that the transition from younger Pleistocene into Holocene starts in the red-brown cohesive clay representing the paleo-soil and not with the beginning of sedimentation of lake chalk.
\end{abstract}

\section{Izvleček}

V članku je analizirana hitrost posedanja Ljubljanskega barja v holocenu. Analiza sloni na reinterpretaciji podatkov iz pelodnih diagramov, ki so bili posneti v vrtini BV-1 severno od Podpeči in v vrtini BV-2 južno od Črne vasi. Reinterpretacija je bila izvedena na podlagi primerjave $\mathrm{z}$ absolutno datiranimi pelodnimi diagrami v sedimentu Podpeškega jezera in diagrami na drugih lokacijah po Sloveniji. Glavni markerji na katerih temelji reinterpretacija so upadanje bora Pinus pri 11,2 ka, ter začetek pojavljanja bukve Fagus in jelke Abies. Koncentracija Fagusa prične naraščati pri 8,7 ka, višek Abiesa pa se pojavi pri 6,4/6,9 ka in $3,0 \mathrm{ka}$. Na podlagi odnosa med starostjo in globino na kateri se pojavlja sediment, je bil postavljen enostaven sedimentacijsko konsolidacijski model, iz katerega izhaja, da je bilo neotektonsko posedanje Ljubljanskega barja v holocenu enakomerno. Posedanje na območju vrtine BV-1 je znašalo $1,24 \mathrm{~m} / \mathrm{ka}$ in posedanje na območju vrtine BV-2 1,36 m/ka. V članku je postavljena tudi hipoteza, da se prehod iz mlajšega pleistocena v holocen prične $\mathrm{v}$ rdečerjavi mastni glini, ki predstavlja paleotla, in ne šele z začetkom sedimentacije jezerske krede - polžarice. 


\section{Introduction}

Ljubljansko barje is a marshy plain extending south of Ljubljana in the direction of Krim. Its western borders are the fringes of the Notranjska plateau, and in the East it is limited by the western Dolenjsko gričevje (Hilly area of Dolenjsko). Ljubljansko Barje is an important aquifer supplying drinking water to a large part of Ljubljana and its wider surroundings. The entire area of Ljubljansko barje is an important archaeological site for both the Neolithic and the later Roman era. The knowledge of morphological development of the Barje area is especially crucial for the earliest settlement. Despite its relatively unfavourable predispositions for construction, Ljubljana is expanding towards the South. This growth is accompanied by a number of problems, including considerable land subsidence and flood protection.

On the basis of available literature it can be established that Ljubljansko barje is relatively well investigated in some segments. There is a long list of published works on this topic, and even more information and data are stored in various work reports. A good overview of older geological and geomorphological literature about Ljubljansko barje can be found in the works of Melik (1946) and Rakovec (1955). A more recent, but popular overview of geology and geomorphology is given by Pavšič (1989), and the latest comprehensive synthesis of drilling results in Ljubljansko barje is provided by Mencej (1990).

In spite of the comprehensive literature, very many geological and geomorphological questions about the development of Ljubljansko barje remain open. It is surprising that a more precise sedimentation model is still not available, and the knowledge about the tectonic development of the Barje basin is relatively poor. Due to the fast opening of the depression in Pleistocene Barje has also a fast and diverse sedimentation, and its entire sedimentation profile represents an important climatic archive. There is not much data available about the climate record in the Ljubljansko barje sediments, especially not data that could be expected on the basis of modern physical and chemical analytical techniques.

In 1959 borehole BV-1 was drilled down to the dolomite basement at the depth of $103.80 \mathrm{~m}$ in the area between Notranje go- rice and Podpeč, and in 1962 borehole BV-2 was drilled south of Črna vas (Fig.1) to the dolomite basement at $116.80 \mathrm{~m}$ (Grimšičar \& Ocepek, 1967; Pohar, 1978). Although many more boreholes down to the Pleistocene basement were drilled at Barje later on (Mencej, 1990, 2002), these are the only deeper ones for which relatively much data was published. Some of these data can be used for statistical analyses, which can serve as the basis for analysing the rate of land subsidence and its development in time.

The discussion about land subsidence at Ljubljansko barje has been going on since the first land drainage activities (Melik,

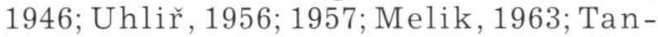
cig, 1965; Breznik, 1975). Because of plans related to more intensive groundwater exploitation in the lower aquifer, discussions regarding this subject have been brought up again lately (Breznik, 1993, 2000; Koler, 2002; Veselič, 2002; Bračič-Železnik et al., 2003). Reasons for land subsidence can be divided into the following groups: subsidence because of the Earth's crust movements, subsidence because of sediment consolidation and subsidence resulting from anthropogenic influences. A similar division of subsidence into groups was first given by Breznik (1993, 2000) and later summarized and upgraded by later authors (Veselič, 2002; Bračič-Železnik et al., 2003). It can be concluded from the published data that the largest subsidences take place in the area of confluence of the Ljubljanica and the Ižica, where they range from 15 to $20 \mathrm{~mm} /$ year. Somewhat lower rates are found in the area between Lipe and Crna vas, amounting to between 5 and $10 \mathrm{~mm} /$ year (BračičŽeleznik et al., 2003). Breznik (1993) assesses that subsidences due to the Earth's crust movements are within the interval of 1 to $2 \mathrm{~mm} /$ year, and subsicences resulting from consolidation between 1.2 and 1.3 $\mathrm{mm} /$ year. The entire subsidence because of natural reasons thus amounts to between 2.2 and $3.3 \mathrm{~mm} /$ year. If we adopt the estimation of naturally induced subsidence according to Breznik (1993, 2000) it can be assessed that the anthropogenically induced subsidence can amount to $16.7 \mathrm{~mm} /$ year. These are relatively high values, causing concern regarding the protection of Ljubljana and surrounding settlements against flooding, because such subsidences take place in areas with the lowest watercourse gradients and thus most prone to flooding. 


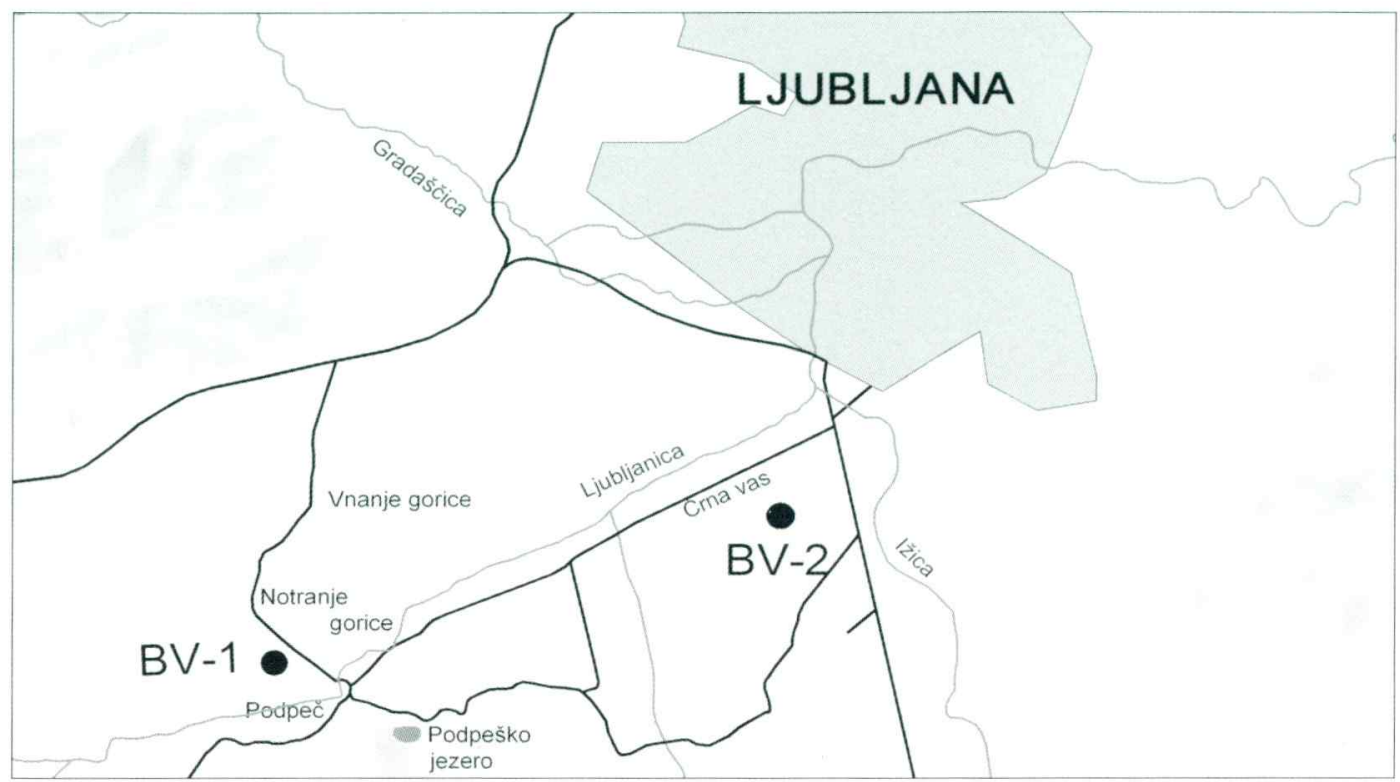

Figure 1. Position of boreholes BV-1and BV-2 at Ljubljansko barje (summarized and adapted according to Grimšičar \& Ocepek, 1967)

Slika 1. Lega vrtin BV-1 in BV-2 na Ljubljanskem barju (povzeto in prirejeno po Grimšičar \& Ocepek, 1967)

This article presents a new evaluation of Ljubljansko barje land subsidence in Holocene. The analysis was carried out on the basis of reinterpretation of published data from boreholes BV-1 and BV-2 (Grimšičar \& Ocepek 1967; Pohar, 1978) and reinterpretation of pollen diagrams from the same boreholes (Sercelj, 1965, 1966). The reinterpretation of pollen diagrams was based on comparison with more recent dating of some pollen diagrams in the wider recharge area of Ljubljansko barje (Gardner, 1997, 1999; Andrič, 2002, 2007; Andrič \& Willis, 2003). The analysis is based also on some published data about the paleoclimate in the larger European space. The methodology used and presented analysis of Ljubljansko barje subsidence has so far not been published in literature.

\section{Methodology}

\section{Sedimentation and consolidation model}

More detailed sedimentation and consolidation models of Ljubljasko barje are not part of our work. These questions are largely left open for further investigations and in- terpretations. The article gives only a "simple" model of surface subsidence, which is only meant to show that land subsidence of Ljubljansko barje is a time-complex process.

On the surface, point $T$ is observed, which is set on the phase border, between the sediment (ground) and water or air. Its coordinates are defined in a rectangular coordinate system, so that $T(x, y, z)$. Changes in the position of point $T$ in time $t$ are observed so that

$$
\frac{d T}{d t}=\frac{\partial x}{\partial t}+\frac{\partial y}{\partial t}+\frac{\partial z}{\partial t}
$$

Let us assume that regarding the regional nature of subsidence treatment horizontal movements compared to vertical movements are negligible. So the rate of subsidence $p_{z}$ of point $T$ is

$$
p_{z}=\frac{d T}{d t}=\frac{d z}{d t}
$$

From the facts given in the introduction chapter it results that the rate of subsidence $p_{z}$ of point $T$ depends on the rate of subsidence $p_{t}$, which is related to the tectonic activity, on the rate of subsidence $p_{k}$, related to the consolidation due to its own weight of sediments, on the rate of subsidence which 
is a consequence of anthropogenic influences $p_{a}$, and on the rate of subsidence $s$. Hence the balance equation

$$
p_{z}+s=p_{t}+p_{k}+p_{a}
$$

Which, written in the differential form is:

$$
\frac{\partial z}{\partial t}=\frac{\partial z_{k}}{\partial t}+\frac{\partial z_{t}}{\partial t}+\frac{\partial z_{a}}{\partial t}-\frac{\partial z_{s}}{\partial t}
$$

Where indexes $k, t, s, a$ represent individual subsidence components.

If the consolidation due to the sediment's own weight can be calculated from its physical activities, the rate of subsidence due to the territory's tectonic activity and sedimentation rate remain unknown. Only indirect conclusions about them can be made on the basis of interpretation. The nature of sedimentation record preserved in the Ljubljansko barje profiles shows that the sedimentation rate was changing throughout the sedimentation time with occasional interruptions. It is very difficult to assess the length of these interruptions.

The model is based on a simple sedimentation-consolidation model of Ljubljansko barje, the realization of which is given in the diagram (Fig. 2), and the record with the partial differential equation given above. The relation between the sedimentation and consolidation (diagenesis) rate and the rate of tectonic movements is observed. It is assumed that at Ljubljansko barje only the subsidence of the basin and not its rising takes place in Holocene. For the needs of our model the sedimentation and consolidation of sediment are merged and named basin filling. If the processes of basin filling and subsidence due to tectonics take place at the same rate, the system is in equilibrium (Figure 2). If the tectonic subsidence is faster than basin filling, then the basin is deepening, and in the case that the filling is faster than tectonic subsidence, the basin is being filled. This construction of the model allows the conclusion that in the case of equilibrium and in the case of stationary processes of filling and subsidence (e.g. sedimentation rate does not change with time) the age of the sediment is in linear relation with the depth at which the sediment is found. This means that the age of the sediment increases linearly with depth. This can be expressed with the equation $g=h S$, where $g$ is - sediment depth, $h$ - sedimentation rate and $S$ - sediment age.

\section{Linear regression}

Analysis of subsidence was made on the basis of linear regression models. The calculation is made for a model where the regression line runs through coordinate origin. Confidence intervals at level $\alpha=0.05$ for a double sided test are given for line slope, using the usual procedure for calculating linear regression (Draper \& Smith, 1998). In calculating the rates of subsidence and their comparison in borehole BV-1 and BV-2 also the testing of regression line slope was carried out. The test is based on the zero hypothesis that subsidences in both populations are equal. The test is performed on the basis of differences in regression line slope $a_{1}$ and $a_{2}$. The test statistics $t$ is defined as

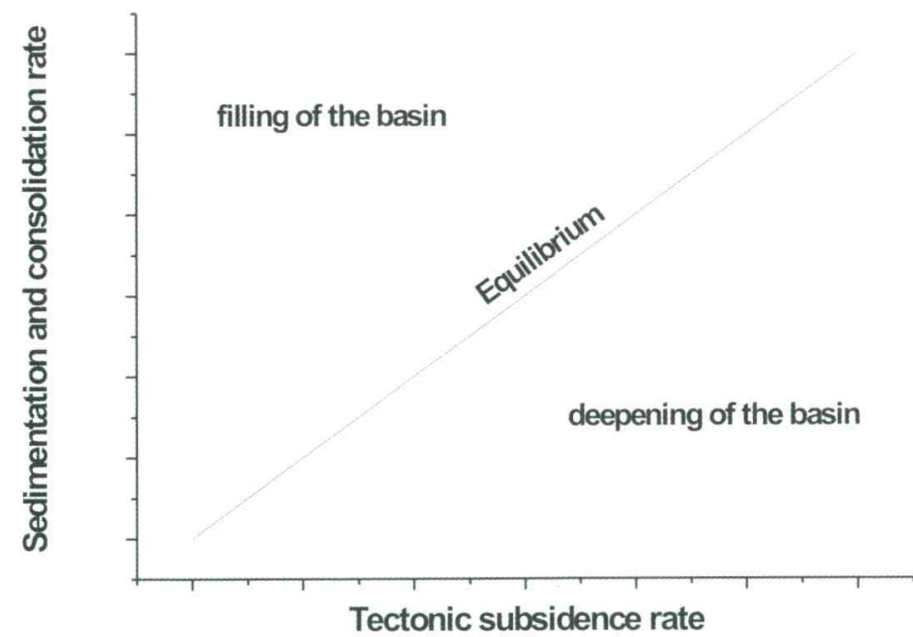

Tectonic subsidence rate
Figure 2. Sedimentation - consolidation model of land subsidence

Slika 2. Sedimentacijsko konsolidacijski model posedanja površine 


$$
t=\frac{a_{1}-a_{2}}{s\left(a_{1}-a_{2}\right)}
$$

So that

$$
s\left(a_{1}-a_{2}\right)=s_{y / x(1)}-s_{y / x(2)}
$$

and

$$
s_{y / x(i)}=\frac{N_{i}-1}{N_{i}-2} s_{i}\left(1-r_{i}^{2}\right)
$$

where

$N$ - is numerus

$r$ - is Pearson's correlation coefficient

The subscript $i$ determines data set. The test statistics $t$ is significant if $t>t(\alpha / 2$, $\left.N_{1}+N_{2}-4\right)$ where $\alpha$ is the degree of significance in the double sided test (Draper \& Smith, 1998).

\section{Pollen diagrams}

In the scope of geological investigations performed on the cores from boreholes BV-1 and BV-2 also palinological investigations were carried out by Šercelj (1965, 1966). These are also the deepest boreholes at Ljubljansko barje for which results of pollen analyses were published. Information about the distribution of pollen in both boreholes can serve as the basis for the estimation of Ljubljansko barje subsidences, above all for the immediate vicinities of the boreholes. It also has to be considered that the interpretation of results is to a large extent limited by the resolution, i.e. the density of borehole sampling. Borehole BV-2 was analysed more in detail than borehole BV-1. Exact depths at which samples were taken are given for borehole BV-2, while for borehole BV-1 they can only be determined approximately from the interpolation of data on the published diagram (Sercelj, 1965).

Only two absolute core dating were performed on both boreholes. In borehole BV-2 two dating were performed with ${ }^{14} \mathrm{C}$ method for samples from the depths of 39.5 and $57.7 \mathrm{~m}$. Ages of over 48,000 years and over 51,000 years were determined (Šercelj, 1966). It is not known whether the ages are obtained directly from measurements or calibrated. These two analyses are unfortunately not relevant for the analysis of subsidence rates in Holocene. Beside data from boreholes BV-1 and BV-2 there are some other paleopalinological data available from Ljubljansko barje and its larger vicinity, however they do not reach as deep as in above mentioned boreholes. Recently data about core dating from the sediment of Jezero near Podpeč (Gardner, 1997; 1999) and data about core dating at Cerkniško jezero (Andrič, 2002, 2007; Andrič \& Willis, 2003) have been published. Beside these data also some other profiles from the larger area of Slovenia (Andrič, 2002, 2007; Andrič \& Willis, 2003) and representative profiles and other data from the larger Central and North European space (Tzedakis et al., 1997; Tinner \& Lotter, 2001; Tinner \& Lotter, 2006; de Beaulieu et al., 2007; Hoek \& Bos, 2007; Sadori, 2007) may be used in the analysis.

Together with palinological data also data were used in the analysis, which render the fluctuation of global climate for the period of sedimentation at Ljubljansko barje. Hence the $\delta^{18} \mathrm{O}$ isotope analysis of Groenland ice GRIP was used as the basis (D ansga ard et al., 1989; Dansgaard et al., 1993; GRIP Members, 1993; Grootes et al., 1993).

The analyses of published pollen diagrams was carried out on the basis of qualitative interpretative cross-comparison between diagrams dated with absolute methods and diagrams of boreholes from cores of BV-1 and BV-2 for which no absolute dating was made. Such comparison turns out adequate especially for the period of Holocene, because only shallower and consequently younger profiles are dated in the larger Barje area. The climatic interpretation of diagrams by Šercelj $(1965,1966)$ was followed to the largest possible extent, while his chronostratigraphic interpretation was not used. Our own chronostratigraphic interpretation was also not performed at the present stage of borehole BV-1 and BV-2 analysis. This interpretation has been left open because it requires a more detailed and profound analysis than that provided in this article. The article determines chronostratigraphically only the border between Pleistocene and Holocene. These determinations are similar to those given for analysed boreholes by previous authors (Šercelj, 1965, 1966; Pohar, 1975). Ages in the article are, except in the Discussion chapter, given in thousands of years with the unit ka (kilo annum).

\section{Results}

From the inventory of $\mathrm{BV}-1$ and $\mathrm{BV}-2$ cores and additional investigations it may be 
concluded that the lithological column can be divided into two parts, the older and the younger part, also because of the fact that data are available mostly for the younger part of the Barje sedimentation profile. Therefore only this part of the profile was analysed further, and it was found out that it belongs to Holocene. Questions addressing deeper regions in the Ljubljansko barje sediments are for now left open.

The GRIP curve of $\delta^{18} \mathrm{O}$ leads to the conclusion that in the period after intensive glaciations two extreme climatic events took place (Dansga ard et al., 1989; Dansgaard et al., 1993; GRIP Members, 1993; Grootes et al., 1993). The event, which corresponds to the age of $11.2 \mathrm{ka}$, is followed by intensive warming up of the atmosphere and the event $8.2 \mathrm{ka}$ is followed by intensive, but short-term cooling down. These extreme events are also reflected in the structure of vegetation. The warming up of the atmosphere since $11.2 \mathrm{ka}$ onwards resulted in a decrease of the proportion of Pinus in the entire pollen pattern (de Beaulieu et al., 2007; Hoek \& Bos, 2007; Sadori, 2007). Such very fast decrease in Pinus can be observed in the core of borehole BV-2 (Šercelj, 1966) from 15,6 m upwards. This trend continues up to the depth of $13.6 \mathrm{~m}$, where the decrease in Pinus is somewhat slowed down. The slowed-down decrease in Pinus is present up to the depth of $10.6 \mathrm{~m}$, and from this depth upwards the $P i$ nus share drops down to a negligible value. So the estimated age of the last maximum Pinus concentration in borehole BV-2 at $15.6-\mathrm{m}$ depth is $11.2 \mathrm{ka}$.

A similar trend can be observed also in the core of borehole BV-1 (Š ercelj, 1965), however no such prominent peak of the Pinus share is present at similar depth as in borehole BV-2. If the peak of Pinus in borehole BV-2 is clear and can also be precisely interpreted with a climatic change at $11.2 \mathrm{ka}$, the diagram of Pinus in borehole BV-1 can only be interpreted together with diagrams of other plants. A maximum of Pinus occurs at depths between $13.4 \mathrm{~m}$ and $14.5 \mathrm{~m}$. This is followed by a very rapid decrease up to the depth of $12.4 \mathrm{~m}$. At $10.4 \mathrm{~m}$ the proportion is increased again, yet lower than at $13.4 \mathrm{~m}$ by almost half. Beyond the depth of $10.4 \mathrm{~m}$ the share of Pinus, like in borehole BV-2, decreases to a negligible value. It is known from data in the larger European space (Tinner \& Lotter, 2006) that very soon after the decrease in Pinus the proportion of Fagus and soon afterwards also the proportion of Abies begin to rise. This is the case also in analyzed boreholes, and the question of dating of these events arises. Some dating from the European space (Tinner \& Lotter, 2001, 2006) show that Fagus starts to occur intensively after the $8.2 \mathrm{ka}$ event, while datings from Slovenia detect these changes 0.5 to $0.6 \mathrm{ka}$ before this event. Gardner (1999) recorded the presence of Fagus and its steep increase in concentration at $8.7 \mathrm{ka}$. Andrič \& Willis (2003) determined the increase in Fagus concentration in the profile of Mlake in Bela krajina at $8.8 \mathrm{ka}$, but found no marked change at this age in the profiles of Gorenje jezero and Praproče. Andrič \& Willis (2003) interpret this change as a time border at which a gradual predomination of shadow-tolerating vegetation takes place. This change is supposed to happen approximately in period $0.1 \mathrm{ka}$. More recent investigations from Central and Northern Europe confirm that the transition to the predomination of Fagus was gradual (Tinner \& Lotter, 2006) and to a large degree locally dependent.

With regard to the immediate vicinity of the profile dated by Gardner (1999), we assume that Fagus starts appearing markedly in the sediments of Barje at $8.7 \mathrm{ka}$. In borehole BV-1 this corresponds to the depth of $10.4 \mathrm{~m}$ and in borehole BV-2 to $11.6 \mathrm{~m}$. Simultaneously with the steep increase of $\mathrm{Fa}$ gus the concentration of Pinus is slightly increased in both boreholes for the last time.

Abies starts occurring in both boreholes almost simultaneously with Fagus, but in a relatively low proportion. Increased contents of Abies occur after the maximum value of Fagus. In borehole BV-1 Abies is present with only one peak at the depth of $4.5 \mathrm{~m}$, and in borehole BV-2 it has two peaks. The first one is found at $8.1 \mathrm{~m}$ depth and the second one at $4.0 \mathrm{~m}$. Let us again have a look at Gardner's (1999) profile of the Podpeško jezero sediment. In this profile a prominent peak of Abies concentration is present at ages $6.4 \mathrm{ka}$ and $6.9 \mathrm{ka}$. The next peak of Abies can be observed at sediment age $3.0 \mathrm{ka}$. So the age of the only peak of Abies in borehole BV-1 can be estimated to $3.0 \mathrm{ka}$. In borehole BV-2 the first peak is estimated at the age of $6.4 \mathrm{ka}$ or $6.9 \mathrm{ka}$, and the second at $3.0 \mathrm{ka}$.

Diagrams for Corylus are also interesting. Gardner (1999) speaks about two pro- 
minent peaks. The first one at age $8.7 \mathrm{ka}$, and the second at $5.8 \mathrm{ka}$. Two peaks are also found in borehole BV-1 The first at $9.3 \mathrm{~m}$ depth and the second at the depth of $5.5 \mathrm{~m}$. In borehole BV-2, however, three peaks can be observed. The first at the depth of $11.6 \mathrm{~m}$, the second at $7.4 \mathrm{~m}$ and the third at $3.6 \mathrm{~m}$. According to Gardner (1999) the maximum of Corylus coincides with the start of the increase of Fagus. This is also the case in borehole BV-2, while in borehole BV-1 the first peak of Corylus appears somewhat later and can thus not be interpreted. In both boreholes the second peak of Corylus occurs at similar depths and has with respect to the morphology of the entire pollen diagram a similar position as in the Gardner (1999) profile. So the age of this peak can be estimated at $5.8 \mathrm{ka}$. The third peak found in profile BV-2 at the depth of $3.6 \mathrm{~m}$ is not found in the Gardner profile and can therefore not be interpreted.

Gardner's (1999) profile of Ulmus can also be of use in dating. In borehole BV-2 a prominent peak of Ulmus is observed at 13.6-m depth. According to its position, slightly before the maximum of Corylus, this peak could correspond to the age of 9.0 ka in Gardner's (1999) diagram. A slight increase of Ulmus is found at the depth of $12 \mathrm{~m}$ in borehole BV-1, but it is not so distinctive as in the later period. Hence this point can be conditionally defined with age $9.0 \mathrm{ka}$.

Results of analysis of local maximum values in pollen diagrams according to Šer- celj $(1965,1966)$ are rendered also in a table (Table 1). The table is constructed so that two values are given for those points of pollen diagrams or events in the climatic history where an unquestionable interpretation was not possible. So the sediment in borehole BV-2 at 8-m depth is aged $6.4 \mathrm{ka}$ or $6.9 \mathrm{ka}$. In borehole BV-1 the sediment with the age $11.2 \mathrm{ka}$ occurs either at $13.4 \mathrm{~m}$ or at $14.5 \mathrm{~m}$.

\begin{tabular}{|r|c|c|}
\hline $\begin{array}{r}\text { Age } \\
\text { [ka] }\end{array}$ & $\begin{array}{c}\text { BV-1 depth } \\
\text { [m] }\end{array}$ & $\begin{array}{c}\text { BV-2 depth } \\
\text { [m] }\end{array}$ \\
\hline 3,0 & 4,3 & 4,5 \\
\hline 5,8 & 5,5 & 7,4 \\
\hline 6,4 & $/$ & 8,0 \\
\hline 6,9 & 10,4 & 11,6 \\
\hline 8,7 & 12 & 13,6 \\
\hline 9,0 & 13,4 & \multirow{2}{*}{15,6} \\
\hline \multirow{2}{*}{11,2} & 14,5 & \\
\cline { 1 - 2 } & \multicolumn{2}{|c}{} \\
\hline
\end{tabular}

Table 1. Reinterpretation of sediment age at different depths in the Holocene period in boreholes BV-1 and BV-2

Tabela 1. Reinterpretacija starosti sedimenta na posameznih globinah za obdobje holocena $\mathrm{v}$ vrtinah $\mathrm{BV}-1$ in $\mathrm{BV}-2$

In addition to the table also a scatter diagram of sediment depth is given in relation to the interpreted age of the sediment (Fig. 3). Data were obtained from the table.
BV-1

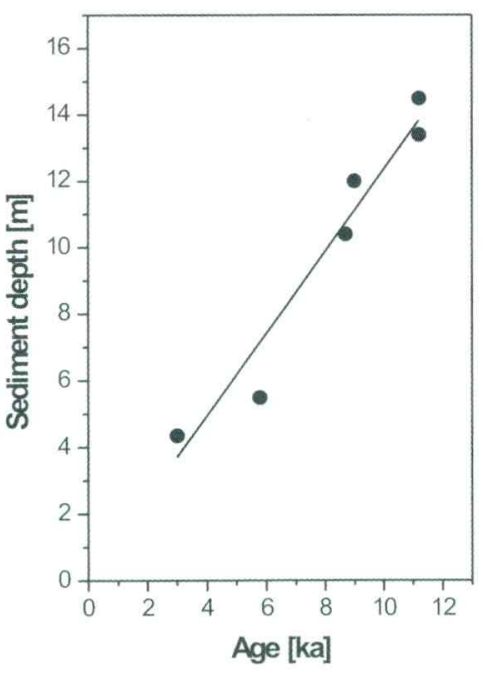

BV-2

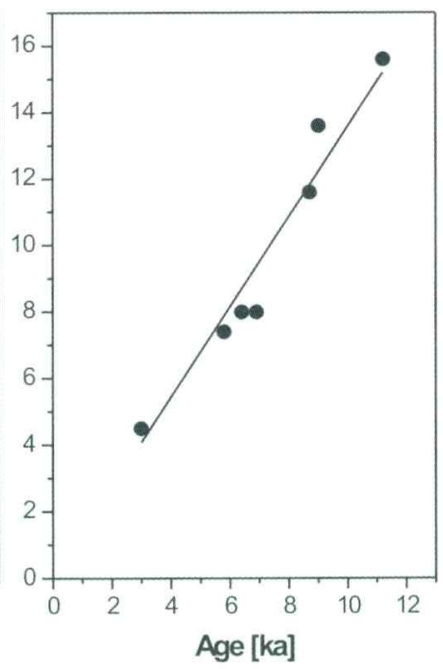

Figure 3. Point diagram of sediment depth in relation to sediment age in boreholes BV-1 and BV-2.

Slika 3. Točkasti diagram globine sedimenta v odvisnosti od starosti sedimenta $v$ vrtinah BV-1 in $\mathrm{BV}-2$ 
Beside points, the diagram shows also linear regression, which was calculated so that the line crosses the coordinate origin. Line slope for borehole BV-1 is $1.235 \pm 0.011 \mathrm{~m} / \mathrm{ka}$ and the correlation coefficient is $\mathrm{r}=0.97$. Line slope for borehole BV-2 is $1.357 \pm 0.005 \mathrm{~m} /$ $\mathrm{ka}$ and the correlation coefficient is $\mathrm{r}=0.98$. The testing of both regression line slopes shows that they are significantly different at level $\alpha=0.05$.

\section{Discussion}

Results obtained from the analysis of pollen diagram ages and consequently from sediment age according to depth are somewhat surprising. The distribution of points, for BV-1 and for BV-2, can be satisfactorily described with linear regression. The correlation coefficients of both lines are high and the confidence intervals are narrow. The comparison of slopes of both regression lines shows that they are statistically typically different.

It is evident from the sedimentation-consolidation model that the slope of the regression line shows the rate of subsidence. In this way the sedimentation rate in the area of borehole BV-1 north of Podpeč is 1.235 $\pm 0.011 \mathrm{~m}$ per 1000 years and in the area of borehole BV-2 south of Črna vas $1.357 \pm$ $0.005 \mathrm{~m} / \mathrm{ka}$ every 1000 years. The difference between the boreholes also corresponds to the thickness of lake chalk, which according to the interpretation of core inventory and pollen diagrams in borehole $\mathrm{BV}-2$ reaches to the depth of $15.15 \mathrm{~m}$, and to the depth of $13.1 \mathrm{~m}$ in borehole BV-1. Differences in subsidence rates show that the central part of Barje, in the part where borehole BV-2 was constructed, subsides faster than the area where borehole BV-1 was constructed. This corresponds to the maps of basement depths compiled for Barje by Mencej (1990).

An evaluation of subsidence rate of Ljubljansko barje due to neotectonics has been, according to available data from literature, so far made only by Breznik (1993, 2000 ). Based on the evaluation of thickness of lake chalk, which according to his data reaches the depth of $13 \mathrm{~m}$, and the hypothesis that it started to deposit 10.000 years ago, he estimated the rate of subsidence of the basement at $1.3 \mathrm{~m}$ every 1000 years (Breznik, 1993). For the area of Log at Vrhnika he estimates the rate of subsidence in the same part at $1.25 \mathrm{~m}$ per 1000 years. In a later article (Breznik, 2000) his estimation is slightly different. On the basis of the hypothetical thickness of lake chalk between $10 \mathrm{~m}$ and $15 \mathrm{~m}$ and the same hypothetical age as in the previous case he estimates that the rates of subsidence of rock basement range from $1.0 \mathrm{~m}$ to $1.5 \mathrm{~m}$ per 1000 years. $\mathrm{He}$ also estimates that the rate of surface subsidence because of consolidation of the sediment's own weight is $1 \mathrm{~m}$ to $2 \mathrm{~m}$ every 1000 years, which gives a joint estimation of subsidence rate from $2 \mathrm{~m}$ to $3 \mathrm{~m}$ every 1000 years (Breznik, 2000). Estimations given by Breznik $(1993,2000)$ are relatively similar to the estimations, which were obtained by means of analysis of pollen diagrams. Breznik's evaluations are made on the presumption that the starting age of lake chalk depositing is 10.000 years. Other evaluations, above all subsidence in the area of Log at Vrhnika (Breznik, 1993) and the evaluation of consolidation (Breznik, 2000) are given only on the basis of expert evaluation. Our analysis partly confirms these evaluations and supplements them with the time component.

Our model leads to the conclusion that the age of the sediment at a given depth is the consequence of cumulative subsidences at this depth, i.e subsidences which are a consequence of neotectonic subsidence and subsidences resulting from the sediment's natural consolidation. Obtained data show that at the temporal distances from 900 to 2,800 years between individual sediment depth ages in the diagram (Figure 3), which can also be regarded as the window through which events are observed, the sediment's subsidence rate is statistically relatively uniform. Data distribution nevertheless indicates that the rate of subsidence in Holocene was not stationary, but is probably the consequence of occasional changes in the rate of subsidence because of neotectonics and changes in sedimentation rate at the bottom of the former lake in which lake chalk was deposited, and consequently of changes in the consolidation rate. According to the theory of sediment consolidation the expected distribution of points on the diagram (Figure 3) would be such that at depths with younger age a faster subsidence rate would be evident, and at greater depths a slower subsidence. Yet this is not the case. Probably this is partly the consequence of the fact that the amount of available data is relatively small and the age estimations are 
subject to major mistakes, and probably this is also the consequence of the fact that lake chalk consolidates (geologically) relatively fast.

Šercelj (1966) made the hypothesis that the beginning of Holocene is related to the horizon where the proportion of cryophilic plants starts decreasing steeply in the diagram. In both boreholes this change occurs within the light-brownish red clay with montmorilonite. On geomechanical profiles of boreholes BV-1 and BV-2 this clay is marked with $\mathrm{AC}$ classification $\mathrm{CH}$ (Grimšičar \& Ocepek, 1967). A relatively low content of $\mathrm{CaCO}_{3}$ is typical of this sediment, while its concentration increases upwards in lake chalk distinctively. Recent paleoclimatic data show that a quick change in the climate of the Northern Hemisphere happened approximately 11,200 years ago (Dansgaard et al., 1989; Dansgaard et al., 1993; GRIP Members, 1993; Grootes et al., 1993). The GRIP curve shows a very fast change in $\delta^{18} \mathrm{O}$ values and with that also warming up and the change of entire climate. In the beginning of Holocene the climate relatively quickly passes from arid to humid and the intensity and quantity of precipitation is much increased (Andrič \& Willis, 2003; Tinner \& Lotter, 2006 and references there in). Pollen diagrams indicate that this climatic change takes place just at the time of sedimentation of red clay. On the basis of mineralogy and colour of this clay a hypothesis can be made that the clay horizon $\mathrm{CH}$ at the depth interval from 13.1 to $15.1 \mathrm{~m}$ in borehole $\mathrm{BV}-1$ and at the depth interval from $15.2 \mathrm{~m}$ to $17.2 \mathrm{~m}$ in borehole BV-2 represents former paleo-soil. The climatic change and the large increase in the quantity of precipitation initiated a gradual re-sedimentation of lake chalk and with that lake formation at Ljubljansko barje.

The analysis of the Ljubljansko barje subsidence, based on the reinterpretation of pollen diagrams from boreholes BV-1 and BV-2 shows that the neotectonic subsidence of the Ljubljansko barje surface is smaller than the subsidence measured with geodetic surveys during the last century, and especially in the last decades. On the basis of this fact a hypothesis can be drawn that much of the subsidence of the Barje surface in the larger confluence area of the Ižica and the Ljubljanica results from anthropogenic influences. The presented interpretations need to be checked also by means of other met- hods, but still the findings in the article confirm existing expert evaluations and show that the subsidence of Ljubljansko barje before the beginning of extensive melioration projects and before the destruction of turf layers was steady and relatively slow.

\section{Conclusions}

Based on the age reinterpretation of individual typical forms of pollen diagrams for individual plant species and genera from boreholes BV-1 (north of Podpeč) and BV-2 (south of Črna vas) it can be concluded that the subsidence of Ljubljansko barje in Holocene was uniform. The subsidence rate of Ljubljansko barje in the area of borehole BV-1 north of Podpeč was $1.235 \mathrm{~m}$ per 1000 years, and in the area of borehole BV-2 south of Črna vas it was $1.357 \mathrm{~m}$ per 1000 years. This subsidence is defined as a consequence of neotectonics. In subsidence estimations it has to be taken into account that the window through which the changes in pollen diagrams are observed and the age of individual typical forms of pollen diagrams are determined is relatively wide, since individual points - sediment depths from which subsidences were calculated - differ largely from each other in age, from 900 to 2,800 years. Lesser differences between points in the subsidence diagram show that in shorter periods of some ten or hundred years the sedimentation and sediment consolidation were not stable in time, and probably also changes in the rate of neotectonicallyinduced subsidence occurred in this time span.

The analyses of the Ljubljansko barje subsidence in Holocene brought up several questions which need to be solved with the reinterpretation of deeper, older parts of boreholes BV-1 and BV-2, and above all with the transfer of data into the larger space of Ljubljansko barje. Future spatial analysis has to be based on climatic models of Quaternary, on sedimentation models, and above all, obtained results need to be supported with the analyses of new cores of the Ljubljansko barje sediment. Up-todate analytical methods and drilling technologies enable the acquisition of quality data, which are quantitatively determined. Analyses and interpretations obtained in this way would not only have scientific but also very practical importance. With its 
spatial development, Ljubljana is expanding towards the south, into the central part of Barje. Therefore numerous construction engineering measures are taken, such as amelioration, filling and loading of ground. Further development of Ljubljana demands a change in drinking water supply and in consequence also larger quantities of abstracted groundwater from deep aquifers of the Barje and its recharge area. Because these are confined aquifers, subsidences of the surface will increase, which can largely endanger the flood safety of the southern part of Ljubljana. Therefore the knowledge of history of Ljubljansko barje subsidence is indispensable. Only in this way the distinction between the anthropogenic and neotectonic component of subsidence can be made and the question to what extent the subsidence is anthropogenically induced can be answered more precisely. Analyses to date show that anthropologically induced subsidence is not negligible.

\section{Acknowledgement}

The results were obtained through the research programme "Groundwater and geochemistry" financially supported by the Slovene Research Agency - ARRS. Special thanks to Erna Urbanc for the original Slovene text translation into English.

\section{References}

Andrič, M. 2002: The Holocene vegetation dynamics and the formation of Neolithic and present-day Slovenian landscape. - Documenta Prehistorica, 28, 133-175.

Andrič, M. 2007: Holocene vegetation development in Bela krajina (Slovenia) and the impact of first farmers on the landscape. - The Holocene, 17, 763-776.

Andrič, M., \& Willis, K. J. 2003: The pyhtogeographical regions of Slovenia: a consequence of natural environmental variation or prehistoric human activity? - Journal of Ecology, 91, 807-821.

Bračič Železnik, B., Veselič, M. \& Vodopivec, F. 2003: Subsidence measurements - marshland subsiding owing to pumping the groundwater. RMZ - Materials and Geoenvironment, 50, 57-60, Ljubljana.

Breznik, M. 1975: Podtalnica Iškega vršaja. - Geologija 18, 289-309, Ljubljana.

Breznik, M. 1993: Arteška podtalnica, posedanja in poplave Ljubljanskega barja - vpliva narave in človeštva. - Razprave 1. posvetovanja slovenskih geotehnikov 2, 11-36, SLOGED, Bled.
Breznik, M. 2000: Antropogeni vplivi na posedanje in poplave Ljubljanskega barja. Slovensko geotehniško društvo, Šukljetovi dnevi 1 , 97-103, Ljubljana.

Dansgaard, W., White, J. W. C. \& Johnsen, S. J. 1989: The abrupt termination of the Younger Dryas climate event. - Nature, 339, 532533.

Dansgaard, W., Johnsen, S. J., Clausen, H. B., Dahl-Jensen, D., Gundestrup, N. S., Hammer, C. U., Hvidberg, C. S., Steffensen, J. P., Sveinbjörnsdóttir, A. E., Jouzel, J. \& Bond, G. C. 1993: Evidence for general instability of past climate from a $250 \mathrm{kyr}$ ice-core record. - Nature, 264, 218-220.

de Beaulieu, J.-L., Tzedakis, P., Ponel, P., Frederic, G. 2007: Pollen records, late Pleistocene/Southern Europe. In: Elias, S.A. (ed.): Encyclopedia of Quanternary Sciences, 2660-2668, Elsevier.

Draper, N. R. \& Smith, H. 1998: Applied Regression Analysis. John Wiley \& Sons Inc., 706 pp., New York.

Gardner, A. 1997: Biotic response to Early Holocene Human activity: results from paleoenvironmental analyses of sediments from Podpeško jezero. Poročilo o raziskovanju paleolitika, neolitika in eneolitika v Sloveniji, 24, 63-77.

Gardner, A. 1999: The ecology of Neolithic environmental impacts - re-evaluation of existing theory using case studies from Hungary and Slovenia. - Documenta Praehistorica 16, 163183.

Grimšičar, A. \& Ocepek, V. 1967: Vrtini BV-1 in BV-2 na Ljubljanskem barju. - Geologija, 10, 279-303, Ljubljana.

GRIP Members, 1993. Climate instability during the last interglacial period recorded in the GRIP ice core. Nature $364: 203-207$.

Grootes, P. M., Stuiver, M., White, J. W. C., Johnsen, S. J. \& Jouzel, J. 1993: Comparison of oxygen isotope records from the GISP2 and GRIP Greenland ice cores. - Nature, 366, $552-554$.

Hoek, W. Z \& Bos, J. A. A. 2007: Early Holocene climate oscilations - causes and consequences. - Quaternary Science Reviews, 26, 1901-1906.

Koler, B. 2002: Določevanje vertikalnih premikov na območju Ljubljanskega barja. V: Brilly, M., Jamnik, B., Bračič-Železnik, B. (ured.): Zaščita vodnih virov in vizija oskrbe s pitno vodo v Ljubljani, 111-115, Ljubljana.

Melik, A. 1946: Ljubljansko mostiščarsko jezero in dediščina po njem. Akademija znanosti in umetnosti v Ljubljani, 223, str., Ljubljana.

Melik, A. 1963: Ob dvestoletnici prvih osuševalnih del na Barju. - Geografski zbornik, 8, 5-64, Ljubljana.

Mencej, Z. 1990: Prodni zasip pod jezerskimi sedimenti Ljubljanskega barja. - Geologija, 31/32, 517-548, Ljubljana.

Mencej, Z. 2002: Varovanje vodonosnikov pod vzhodnim delom Ljubljanskega barja. V: Brilly, M., Jamnik, B., Bračič-Železnik, B. (ured.): Zaščita vodnih virov in vizija oskrbe s pitno vodo v Ljubljani, 67-73, Ljubljana.

Pav̌̌ič, J. 1989: Ljubljansko barje v geoloških obdobjih. Zavod SR Slovenije za varstvo naravne in kulturne dediščine, 69. str., Ljubljana. 
Pohar, V. 1978: Granulometrična analiza sedimentov z Ljubljanskega barja. - Rudarsko metalurški zbornik, 2-3, 177-186, Ljubljana.

Rakovec, I. 1955: Zgodovina Ljubljane 1. Geologija in arheologija, 11-207, Ljubljana.

Sadori, L. 2007: Pollen records, postglacial/Southern Europe. In: Elias, S.A. (ed.): Encyclopedia of Quaternary Sciences, 2763-2773, Elsevier.

Šercelj, A. 1965: Paleobotanične raziskave in zgodovina Ljubljanskega barja. - Geologija, 8, $5-27$, Ljubljana.

Sercelj, A. 1966: Pelodne analize pleistocenskih in holocenskih sedimentov Ljubljanskega barja. Razprave SAZU IX/9, 431-472, Ljubljana.

Tancig, R. 1965: Pedološke značilnosti Ljubljanskega barja. - Geologija, 8, 58-78, Ljubljana.

Tinner, W. \& Lotter, A.F. 2001: Central European vegetation response to abrupt climate change at $8.2 \mathrm{ka}$. - Geology, 29, 551-554.

Tinner, W. \& Lotter, A.F. 2006: Holocene expansion of Fagus silvatica and Abies alba in Central Europe: where are we after eight dec- ades of debate? - Quaternary Science Reviews, 25, $526-549$

Tzedakis, P. C., Andrieu, V., de Beaulieu, J. L., Crowhurst, S., Follieri, M., Hooghiemstra, H., Magri, D., Reille, M., Sadori, L., Shackleton, N. J., Wijmstra, T. A. 1997: Comparison of terrestrial and marine records of changing climate of the last 500.000 years. - Earth and Planetary Science Letters, 150, $171-176$

Uhliř, H. 1956: Historiat osuševalnih del na Ljubljanskem barju - Prva knjiga. Uprava za vodno gospodarstvo Ljudske republike Slovenije, 113 str., Ljubljana.

Uhliřr, H. 1957: Historiat osuševalnih del na Ljubljanskem barju - Druga knjiga. Uprava za vodno gospodarstvo Ljudske republike Slovenije, 125 str., Ljubljana.

Veselič, M. 2002: Analiza posedanja Ljubljanskega barja zaradi črpanja vode v zvezi z načrtovanim vodnjakom V-2Agl v vodarni Brest. V: Brilly, M., Jamnik, B., Bračič-Železnik, B. (ured.): Zašcita vodnih virov in vizija oskrbe s pitno vodo v Ljubljani, 83-93, Ljubljana. 